\title{
ECOLOGY
}

\section{PLAGUE ON THE PRAIRIES}

TED LEIGHTON, Canadian Cooperative Wildlife Health Centre, Western College of Veterinary Medicine, University of Saskatchewan, Saskatoon, SK S7N 5B4

It is unexpected news that bubonic plague is alive and well and living on the Canadian prairies, yet such is the case. The same bacterium that caused the Black Death of European history today lives quietly in our own land among mice and fleas, tucked away in burrows and runways beneath the prairie landscape, hidden by the thatch of needle and thread grass and Blue Grama, sheltered under glacial erratics and tipi rings and in the abandoned galleries of pocket gophers. That it lives among us, a part of nature in prairie Canada, is certain. Where and how it lives, exactly, we do not know.

It seems preposterous that we could live side by side with bubonic plague!
Why is this not in the papers and on the evening news? But plague was in the news as recently as 1992 when it infected a hunter in nearby Montana, and again in 1987, when it infected another in the same state. ${ }^{9}$ And it must have been in the news in 1939 when a farmer and mink rancher near Stanmore, Alberta died of plague. He contracted the disease by cutting himself while skinning his unexpectedly dying mink which he had recently fed an unusual abundance of suddenly dying ground squirrels: all victims of plague. $^{4}$

Plague is a newcomer to our prairie landscape, as new as raccoons and starlings. As far as can be determined,

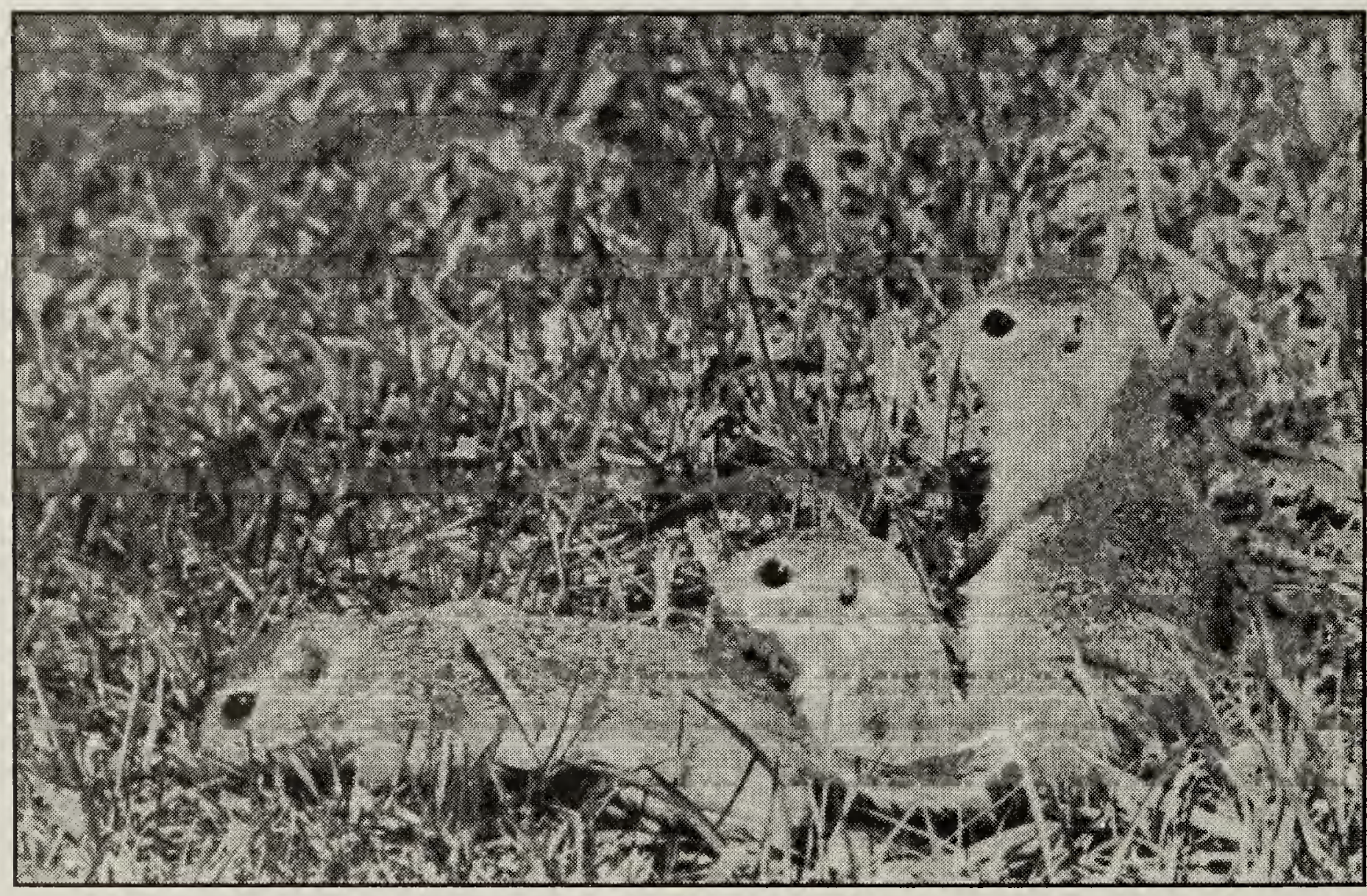


its native home is on the steppes of eastern Asia. There it was, and is still, a bacterium that lives in a cycle of transmission between several species of small rodents and their fleas. Neither the rodents nor the fleas appear to suffer much ill health when they are infected by the bacterium, known to science as Yersinia pestis. So the bacterium persists in these rodent-flea communities as a rather benign parasite. However, many other species of rodent suffer severe and fatal disease when infected with this bacterium, among them ground squirrels, marmots and various species of rats. Some fleas suffer from plague as well. In one common species of rat flea, the bacterium plugs up the digestive system and goads the infected fleas into a frenzy of biting anything warm-blooded, including people, spreading infection with every bite as they attempt to relieve their fatal hunger. $2,6,10,11$

The usual source of infection for people is a bite from an infected rodent flea, and the result, in the absence of antibiotics, is death about $60 \%$ of the time. Plague most often is not contagious from one person to another, and each new case arises from a flea bite. But the course of the disease in people is quite variable, and if the victims develop pneumonia during their illness, their every breath and cough become a potent source of infection for other people nearby. Those who become infected by way of such aerosols will themselves immediately develop pneumonia, which is quickly fatal, but which also includes some hours of exhaling the bacterium and infecting others in attendance. Thus, epidemics can result from exposure of many people to infected fleas, as when rats and their fleas in towns and cities acquire plague, or the disease can spread like wildfire from person to person when it takes the form of pneumonia. ${ }^{2,6,11}$
The plague bacterium was an early world traveller. ${ }^{11}$ Through infection of people who invaded its natural steppeland habitat, and of the rats and fleas that often accompanied them, it was carried to the coastal cities of Asia as they developed in the last two millennia $B C$, and then to more distant lands. Plague began its first recorded sojourn in Europe in about 542 AD, arriving on the Egyptian shores of the eastern Mediterranean and spreading west and north as far as Scandinavia. It arrived in a Europe that was severely overpopulated and that had, at best, an intermittent social order. Some estimate that plague killed as many as 100 million people in the course of 60 years. The epic poem Beowulf is set at about the time when plague arrived in northern Europe, and recounts the devastation of the Danes at the hands of one Grendel, "a fiend out of Hell" who "began to work his evil in the world". "It seems possible that this new unprecedented murderous force, symbolized by Grendel and against which all available defences were ineffectual, might have been plague.

Plague revisted Europe again from about 1350 to 1800 , this time arriving on the shores of the Black Sea. Europe was again over-populated, wars still raged and cities had grown large but were without effective sanitation. In the 2-3 years centred on 1350 , total mortality of people due to plague was staggering, in the range of $25-70 \%$ of regional populations and at least $25 \%$ of the total population. Epidemics swept back and forth across Europe for the next 450 years. Plague ended in Europe some time in the early 1800 s, and no one really understands why. Its disappearance was coincident with the evolution of a degree of regional economic stability and of new social order brought about by renaissance, reformation, enlightenment, emigration 
and the effects of plague itself. Despite its devastating march through human populations, plague never found an ecological niche in Europe - no community of wild rodents and fleas among which it could establish a permanent home. It simply disappeared. ${ }^{10,11,13}$

The next major expansion of plague out of Asia occurred in the late 1800s. Epidemics developed in southern China in the 1860 s and reached coastal cities, including Hong Kong, where in 1894 Alexandre Yersin first determined that this terrible disease is caused by a bacterium, which now bears his name. Its mode of transmission by fleas was discovered only in 1898. Thus, human understanding finally caught up with plague after about 4000 years of close association. Plague and the age of fast steamships arrived in Asian seaports simultaneously in the late 1800 s, and, by means of rats on those ships, the disease was quickly transported all over the world - to Africa, and to South and
North America, where, on each continent, it found new and hospitable communities of native wild rodents and fleas, and was incorporated into their ecosystems.

Plague became established among wild rodents in North America about 1900 , around the busy port of San Francisco where it first was recognized as a cause of death in California Ground Squirrels (Spermophilus beecheyi) in 1908. Slowly, it spread eastward, establishing itself here and there across the western mountains and out onto the plains. ${ }^{6}$ The impact of plague on these newly invaded ecosystems has never been determined, but some native species, including ground squirrels (Spermophilus sp.) and prairie dogs (Cynomys sp.), are highly susceptible to the disease. 4,6 Plague has totally eliminated vast prairie dog colonies extending over many square kilometres, in a matter of weeks. ${ }^{2,12}$ It seems possible that the arrival of plague on the western prairies may have played a role

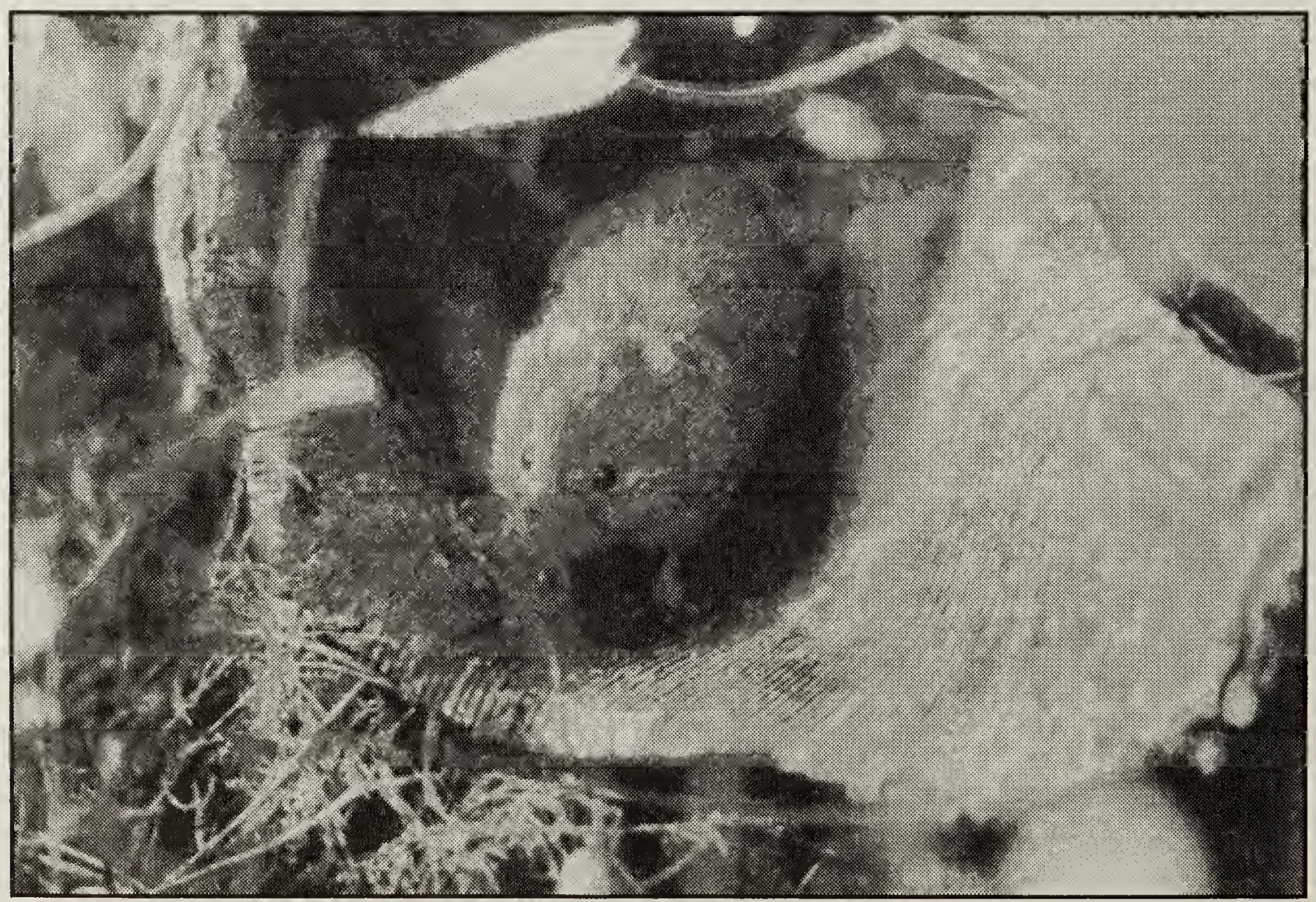


in the demise of the Black-footed Ferret (Mustela nigripes), a little weasel entirely dependent on prairie dogs as prey and only just rescued from the brink of extinction in the 1980s. ${ }^{12}$

Plague always has commanded the attention of human societies. Its arrival in North America sparked surveys by public health authorities and forays into wild habitats to determine where it is and how it lives., ${ }^{2,} 6$ These efforts have provided a partial portrait and natural history of plague in North America. The bacterium appears to infect and persist among several native species of mice and voles - deer mice (Peromyscus), meadow voles (Microtus) and grasshopper mice (Onychomys) for example - among which it lives, as it does on the steppes of Asia, as a parasite certainly, but not an important cause of disease. It lives in communities of these rodents and their fleas in scattered arid environments from the Pacific coast to some uncertain distance out on the prairies east of the Rockies, south into Mexico, north an unknown distance into Canada.

Canadian public health officials initiated surveys for plague in British Columbia and Alberta in 1938, and these were extended to include Saskatchewan and Manitoba from 1939 to $1946 .{ }^{3,5}$ These were not trivial undertakings; 62,369 rodent fleas were collected and tissue samples were taken from 20,212 ground squirrels. These specimens were pooled and inoculated into 2,239 guinea pigs. The plague bacterium was detected in 40 of those 2,239 sample pools, in specimens from British Columbia, Alberta and Saskatchewan. However, after 1946 plague was made less fearsome by the advent of effective antibiotic drugs, and, in western Canada, it was forgotten. The federal Laboratory of Hygiene in Kamloops, from which the plague surveys had been conducted, was closed, its records lost or discarded. No case of plague in man or beast has been recognized in interior Canada since the 1939-46 surveys, except for two Bushytailed Woodrats (Neotoma cinerea) found dead of the disease near Lillooet, $B C$ in $1988 .^{8}$ But plague has not decamped from its new prairie home. A survey of farm dogs conducted in the summer of 1995, in Saskatchewan around the western block of Grasslands National Park and Saskatchewan Landing Provincial Park, and in Alberta around Dinosaur and Writing-On-Stone Provincial Parks, found that about 10\% of the dogs in these areas had had contact with the plague bacterium within the previous 4-8 months, probably from hunting wild rodents. ${ }^{?}$

To what extend does plague threaten human health on the Canadian prairies? Probably we have no more to fear from plague than we do from rattlesnakes or lightning, and much less to fear from these than from the hazards of the highway. Yet, as sure as there are rattlesnakes and lightning, there also is plague. In the western United States, 1020 human cases of plague occur each year, and about 1 in 7 of these is fatal. Most cases occur in the American southwest, among people who live near or within habitat highly favourable to the plague bacterium and its rodent hosts. Until recently, these victims were nearly all from rural areas, but as the suburbs of Santa $\mathrm{Fe}$ and Albuquerque have expanded into plague's territory, the number of suburban cases has increased. The major risk factor identified for people is close living with wild rodents, and the major recommendation to reduce risk of infection is to maintain house and yard in a manner unattractive to rodents..$^{10} \mathrm{In}$ some public parks, the risk of infection for campers and picnickers has been reduced with flea powder, applied to 
burrow entrances and to the backs of mice, squirrels and chipmunks which visit small bait stations built for this purpose. Residents and visitors to habitat known to harbour plague are advised to use the common sense technologies of high socks, long pants and insect repellent to avoid flea bites as they hike, and not to sleep on rodent burrows. ${ }^{2,10}$

Public health authorities have not tried to understand where and how plague lives in prairie Canada since 1946. The prairie dweller who seeks medical attention because of general illness, aches, pains and fever is likely to receive a course of antibiotics and to return to good health, but is unlikely to have a blood sample taken for laboratory diagnosis of plague. Thus, we know more about plague in dogs and wildlife in prairie Canada than we do about its risks to people. Do the fringes and suburbs of Kamloops or Kelowna, of Calgary, Lethbridge or Medicine Hat, of Swift Current, Moose Jaw or Regina, or of Brandon brush up against plague? It is clear from American studies that the risk of infection for people is much higher at times when there are outbreaks of the disease among susceptible wild rodents, such as ground squirrels and prairie dogs, than it is in years when such outbreaks do not occur. An example is the severe outbreak of plague that occurred among Richardson's Ground Squirrels (Spermophilus richardsoni) in 1939 over an area of at least 370 square kilometres (144 square miles) in the general region of Hanna, Alberta, which took one human life. ${ }^{4}$ Yet, with little effort made toward surveillance of plague, the good and bad years in western Canada go unrecognized and neither health authorities nor the public can know when or where risks may be high.

Prairie naturalists are a hardy lot, well schooled in techniques of clothing and bug dope to defend against ticks and mosquitoes, with their noisome bites and sometimes nasty diseases. These practical defences will keep off fleas and plague in like manner. General illness, aches, pains and fever should receive prompt attention from a physician. Such precautions are enough to manage the current risk of plague. But the ecology of plague and the risk it poses to people are dynamic and likely to change with changing conditions. A shift to a warmer climate, for example, is likely to favour plague on the prairies. It also is probable that outbreaks like the one among Alberta ground squirrels in 1939 will, from time to time, occur again, and they will carry with them increased risk of transmission of plague to people. Thus, plague bears watching. The Black Death, though hidden under sweet grass and prairie crocus, is the Black Death, nonetheless.

1. Anonymous. (650-900AD). Beowulf. As presented in Heaney, S. 2000. Beowulf. A New Verse Translation by Seamus Heaney. Farrar, Straus and Giroux, New York, N.Y. Lines 100-101.

2. Barnes, A.M. 1982. Surveillance and control of bubonic plague in the United States. Symposium of the Zoological Society of London, No. 50, 237-270.

3. Gibbons, R.J. 1939. Survey of Rocky Mountain spotted fever and sylvatic plague in western Canada during 1938. Canadian Public Health Journal 30:184187.

4. Gibbons, R.J. and F.A. Humphreys. 1941. Plague surveys in western Canada. Canadian Public Health Journal 32: 24-28.

5. Humphreys, F.A., and A.G. Campbell. 1947. Plague, Rocky Mountain spotted fever and tularemia surveys in Canada. Canadian Journal of Public Health 38:124-130. 
6. Kartman, L., M.I. Goldenberg and W.T. Hubbert. 1966. Recent observations on the epidemiology of plague in the United States. American Journal of Public Health 56:1554-1569.

7. Leighton F. A., H.A. Artsob, M.C. Chu and J.G. Olsen. A serological survey of rural dogs and cats on the southwestern Canadian prairie for zoonotic pathogens. Canadian Journal of Public Health 92: 67-71.

8. Lewis, R.J. 1989. Plague in bushytailed woodrats. Canadian Veterinary Journal 30:596-597

9. Montana Department of Public Health and Human Services. 1987, 1992. Internal Reports. Helena.
10. Poland, J.D., T.J. Quan, and A.M. Barnes. 1994. Plague. In: Handbook of Zoonoses, $2^{\text {nd }}$ Ed, Section A. (G. W. Beran, ed.) CRC Press, Boca Raton. pp. 93-112.

11. Pollitzer, R. 1954. Plague. W.H.O. Monograph Series, No. 22. World Health Organization, Geneva. 698 p.

12. Ubico, S.R., G.O. Maupin, K.A. Fagerstone and R.G. McLean. 1988. A plague epizootic in white-tailed prairie dogs (Cynomys leucurus) of Meeteetse, Wyoming. Journal of Wildlife Diseases 24: 399- 406.

13. Velimirovic, B. and $\mathrm{H}$. Velimirovic. 1989. Plague in Vienna. Reviews of Infectious Diseases 11: 808-826.

"The Malagasy Republic on the island of Madagascar ranks among the top five countries in the world in terms of endemism - the percentage of its total species found there and nowhere else. Roughly 54 percent of its butterflies, 95 percent of its reptiles, 46 percent of its birds, 41 percent of its bats, all of its primates and all of its thousands or so orchids are unique to the island. By the 1990s only 10 percent of Madagascar's original forest cover remained intact and less than 2 percent of its land base had achieved nominal protection."

Stephen L. Buchmann and Gary Paul Nabhan, The Forgotten Pollinators, 1996. p. 135 